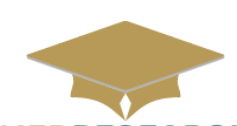

MEDRESEARCH

www.medresearch.in

\author{
2014 Volume 1 Number 1 April-June
}

\title{
A rapid appraisal of training issues of ASHAs (Accredited Social Health Activist) in Madhya Pradesh
}

\author{
Kant Guleri S. ${ }^{1 *}$, Dixit S. ${ }^{2}$, Sakalle S. ${ }^{3}$, Bhagwat A. ${ }^{4}$, Yesikar V. ${ }^{5}$, Pandey D. ${ }^{6}$ \\ DOI: https://doi.org/10.17511/ijphr.2014.i1.02
}

\footnotetext{
1* Sunil Kant Guleri, PG Resident, Department of Community medicine, MGM Medical College, Indore, Madhya Pradesh, India.

2 Sanjay Dixit, Professor \& Head, Department of Community medicine, MGM Medical College, Indore, Madhya Pradesh, India.

3 Salil Sakalle, Associate professor, Department of Community medicine, MGM Medical College, Indore, Madhya Pradesh, India.

${ }^{4}$ A K Bhagwat, Professor, Department of Community medicine, MGM Medical College, Indore, Madhya Pradesh, India.

5 Veena Yesikar, Associate Professor, Department of Community medicine, MGM Medical College, Indore, Madhya Pradesh, India.

6 Dhruvendra Pandey, PG Resident, Department of Community medicine, MGM Medical College, Indore, Madhya Pradesh, India.
}

Introduction: ASHAs (Accredited Social Health Activist) act as a 'bridge' between the rural people and health service outlets and play a central role, in achieving national health and population policy goals. Their effectiveness largely depends on the training and support from health system and the community. Training is the backbone of capacity building and functioning of ASHAs. Material and methods: A cross sectional study done in Indore and Dewas districts of Madhya Pradesh in year 2013. Facility survey of training centre, observation of training micro plan and its implementation and trainees feedback (satisfaction) regarding training using structured Performa was done. Feedback from 270 ASHA from Indore and 310 ASHAs from Dewas selected by sequential random sampling was recorded. For statistical analysis Mann whitney $U$ test was applied and $p$ value less than 0.05 was considered significant. Observations: one of the training centre lacked basic facilities like separate dormitories, mess, dining hall, adequate number of toilets. Delay in the running of session was seen and ASHAs come late at the training centre on first day. Feedback revealed that 70 $\%$ of the participants were satisfied with objectives, $94 \%$ agreed with course material adequacy and utility and $74 \%$ agreed with their teaching efficiency. But only $65 \%$ were satisfied with the overall facilities at the training centres. Conclusion: there were deficiencies in the facilities for proper conduction of training which can be improved for better outcome of the training and functioning of ASHAs.

Keywords: Activist, Facility, Feedback, Training

Corresponding Author

Sunil Kant Guleri, PG Resident, Department of Community medicine, MGM Medical College, Indore, Madhya Pradesh, India.

Email: drsunilmdpsm@gmail.com
How to Cite this Article

Guleri SK, Dixit S, Sakalle S, Bhagwat AK, Yesikar V, Pandey D. A rapid appraisal of training issues of ASHAs (Accredited Social Health Activist) in Madhya Pradesh. Public Health Rev Int J Public Health Res. 2014;1(1):3-8.

\section{Available From}

https://publichealth.medresearch.in/index.php/ijphr/ article/view/2
To Browse

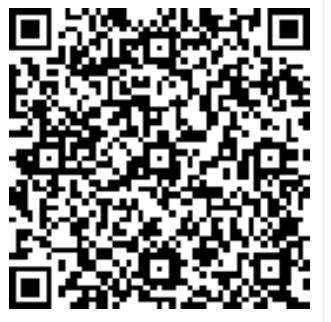

Manuscript Received 2014-04-15

Conflict of Interest No

Review Round 1
2014-04-26
Funding
Nil

Review Round 1

Nil

Review Round 2
2014-04-29
$\begin{gathered}\text { Ethical Approval } \\ \text { Yes }\end{gathered}$

Review Round 3

Plagiarism X-checker $9 \%$
Accepted 2014-05-15

Note (c) 2014 by Sunil Kant Guleri, Sanjay Dixit, Salil Sakalle, A K Bhagwat, Veena Yesikar, Dhruvendra Pandey and Published by
Siddharth Health Research and Social Welfare Society. This is an Open Access article licensed under a Creative Commons Attribution 4.0 International License https://creativecommons.org/licenses/by/4.0/ unported [CC BY 4.0]. 


\section{Introduction}

ASHA (Accredited Social Health Activist) is a health activist(s) in the community who creates awareness on health and its social determinants, mobilize the community towards local health planning and increased utilization and accountability of the existing health services [1]. She acts as a 'bridge' between the rural people and health service outlets and would play a central role, in achieving national health and population policy goals [2] [3].

Training of ASHA workers has been started since the implementation of ASHA programme under National Rural Health Mission in year 2005. Various changes like inclusion of skill based training instead of earlier modular training of module 1 to 4 has been done based on the various evaluation of the ASHA programme done biannually by National health system resource centre and other studies [4]. The detailed guidelines regarding ASHA training has been given in guidelines for community process [5].

Madhya Pradesh one of the high focus states under NRHM has recruited almost $98 \%$ of the proposed ASHAs to be selected [6]. And almost 75 percent of them are already trained in the initial 5 modules of induction training. The health/ training department is now training them in skill based training (6th and 7 th module). The effectiveness of ASHA workers largely depends on the training and support from health system and the community [7]. Since training is the backbone of capacity building and functioning of ASHAs, evaluation of training issues is of prime importance. In this study facility survey of training centre, observation of training micro plan and its implementation and trainees feedback (satisfaction) regarding training has been done.

\section{Subject and Methods}

A cross sectional study done in Indore and Dewas districts of Madhya Pradesh in year 2013. Since the training was undergoing only at district training centres the same were selected for study. Facility survey of these centres was done using a check list derived from evaluation checklist of AWTC (Aaganwadi Training Centre) and MLTC (middle level training centre) in ICDS (Integrated Child Development Scheme) programme.The training in charges were interviewed regarding development of training micro plan and the training activities were observed passively by the authors to assess training progress and plan implementation.
Feedback regarding training was assessed in 270 ASHA from Indore and 310 ASHAs from Dewas, selected by sequential random sampling among ASHAs who attended training and gave verbal consent (sample size calculated by formula Z2pq/c2, confidence limit of $95 \%$, error level of $5 \%$ and $p=$ $50 \%)$ [8].

Feedback Performa consisted of five point Likert's scale for satisfaction regarding achievement of objectives, the quality and completeness of course material, the teaching activity of trainers and other facilities required for conduction of training; developed using sample evaluation form derived from user guide and resource manual of workforce development plan template [9]. The data was entered into excel spread sheets and analysed using SPSS software. Mann whitney $U$ test was applied and $p$ value less than 0.05 was considered significant.

\section{Results}

Skill based training of ASHAs in Madhya Pradesh was organised as a 20 days residential programme scheduled in four rounds, each of five days, organised Monday to Friday in a week. The second round of this training as observed in this study was focussed on neonatal and child care.

It included the care of new born at the time of delivery, cord care, eye care, care of sick newborn child, preventing newborn from hypothermia, initiation and continuation of correct breastfeeding practices and assessment of sick child (diarrhoea, acute respiratory infections and malaria), dehydration and demonstration of (oral rehydration solution) ORS preparation. The training was managed by training in-charge appointed by the selected NGO.

Government and district health administration had no role in organising training except for selecting NGO and trainers. Training was organised by NGO Bhartiya Mahila Gramin Sangh and Asra Samajik Lok Kalian Samiti in Indore and Dewas respectively. ASHAs from a particular development block were called for training in a batch of 30 participants including ANM (Auxillary Nurse Midwife) and LHV (Lady Health visitor) of that area.

Table-1: Training issues concerned to training centres: 


\begin{tabular}{|l|l|l|l|}
\hline S. & \multicolumn{1}{|c|}{ Facilities } & Indore & Dewas \\
\hline 1. & $\begin{array}{l}\text { Availability of fixed venue / Building with } \\
\text { residential capacity }\end{array}$ & Yes & Yes \\
\hline 2. & Training centre accessibility - connection to major & Yes & No \\
\hline r. & Lectures halls with adequate sitting capacity & Yes & Yes \\
\hline 4. & Light and ventilation of the lecture halls & Adequate & Adequate \\
\hline 5. & Audio visual aids, black/white board, LCD & Yes & Yes \\
\hline 6. & Separate hostel facility/dormitory & & \\
\hline 7. & Dining hall and mess & Yes & No \\
\hline 8. & Sufficient indoor and outdoor space & Yes & No \\
\hline 9. & Separate toilet facility other then with lecture hall & Yes & No \\
\hline 10. & Safe Drinking water & Yes & Yes \\
\hline 11. & Health care facility / clinic & Yes & No \\
\hline 12. & Library & Yes & No \\
\hline 13. & Crèche facility/children park & No & No \\
\hline 14. & Notice board for the display of information/ & No \\
\hline
\end{tabular}

There was lack of some facilities at both the district training centre. But Dewas training centre lacks basic facilities like dormitories, mess and the toilets/ bathroom and lecture halls were utilised for residence also.

\section{Training plan}

Training plan for training was made well in advance for all ASHAs divided in several batches, each batch of 30 ASHAs. The list of ASHAs to be trained in particular batch was received from the CMOs office and sent to the Block Community Mobiliser (BCM) of the concerned block, 15 days in advance. The BCM informs the concerned ANM, LHV and the ASHAs included in the list and direct them for training.

\section{Training process}

Participants come by their convenience to their training centres and were provided with travelling allowance. Training undergo as per the sequence of schedules issued by state govt. Accommodation and food facility was provided free of cost (govt. fund) to the trainees and trainers.

After the training hours, the trainees were left for recreational activities and group discussions. Two trainers stay at the training centre in night to keep vigil over the trainees and help them when ever required.

The training schedule was of five continuous days, the 4th day of which was fixed for field training and 5 th day for evaluation/ theory and practical exams.
The cheques of TA/DA were distributed to each participant on the last day of training before the trainees leave from training centre.

Table-2: Training issues concerned with training plan, process and implementation, finding of passive observation

\begin{tabular}{|c|c|c|c|}
\hline s. & Key findings & Indore & Dewas \\
\hline 1. & $\begin{array}{l}\text { Inauguration of the training sessions as per } \\
\text { scheduled time }\end{array}$ & No & No \\
\hline 2. & $\begin{array}{l}\text { All the participants come before the start of training } \\
\text { session }\end{array}$ & No & No \\
\hline 3. & $\begin{array}{l}\text { Registration of the participants before start of } \\
\text { training }\end{array}$ & Yes & Yes \\
\hline 4. & $\begin{array}{l}\text { Distribution of training kit and stationary to the } \\
\text { ASHAs }\end{array}$ & Yes & Yes \\
\hline 5. & Batch size limited to 30 participants & Yes & Yes \\
\hline 6. & $\begin{array}{l}\text { Formal introduction and recap of the previous } \\
\text { training session }\end{array}$ & Yes & Yes \\
\hline 7. & $\begin{array}{l}\text { Children accompanying mothers / participants in the } \\
\text { class }\end{array}$ & Yes & Yes \\
\hline 8. & Children causing hindrance in the training & Yes & Yes \\
\hline 9. & Trainers stick to the topics as per schedule & Yes & Yes \\
\hline 10. & $\begin{array}{l}\text { Cross questioning from participants and explanation } \\
\text { by trainers }\end{array}$ & Yes & Yes \\
\hline 11. & $\begin{array}{l}\text { Orientation of all the participants throughout the } \\
\text { lecture }\end{array}$ & No & No \\
\hline 12. & $\begin{array}{l}\text { Availability of additional material charts, models, } \\
\text { dummies }\end{array}$ & Yes & Yes \\
\hline 13. & Daily Assignments given to the trainees & Yes & Yes \\
\hline 14. & All registered participants go to field visits & Yes & Yes \\
\hline 15. & $\begin{array}{l}\text { All participants go through theory and practical } \\
\text { exams }\end{array}$ & Yes & Yes \\
\hline 16. & $\begin{array}{l}\text { All participants get the remunerations/TA /DA for } \\
\text { training }\end{array}$ & Yes & Yes \\
\hline
\end{tabular}

\section{Feedback of the participants regrinding training}

Among the 580 ASHAs included in the study 3/4th (74\%) had eligible qualification of class 8 th and above while the rest $1 / 4$ th $(26 \%)$ were without eligible qualification, and selected due to unavailability of qualified candidates.

The mean age of ASHAs was 28 years with a range of 17 to 58 years

Feedback regarding completion of training objectives: Almost $75 \%$ trainees agreed that the objectives of the training were fulfilled while $10 \%$ completely disagree with this. 
Table-3: Comparison of Indore and Dewas for satisfaction regarding completion of training objectives:

\begin{tabular}{|c|c|c|c|c|}
\hline Mann-Whitney U test & $\begin{array}{l}\text { Mean rank } \\
\text { Indore }\end{array}$ & $\begin{array}{l}\text { Mean rank } \\
\text { Dewas }\end{array}$ & Z score & P value \\
\hline \multicolumn{5}{|l|}{ Objectives: } \\
\hline 1. To take care of the newborn, support and help the mother to breastfeed, and to keep the baby warm. & 329.06 & 256.92 & -6.729 & .000 \\
\hline 2. Counsel mother for breastfeeding and Emphasise importance of early and exclusive breastfeeding. & 319.60 & 265.15 & -4.923 & .000 \\
\hline 3. Identify the newborn with fever and hypothermia and Teach mothers how to keep the newborns warm & 314.50 & 269.60 & -4.002 & .000 \\
\hline $\begin{array}{l}\text { 4. Communicate essential messages for prevention of malnutrition, advice on feeding and on prevention of } \\
\text { illness, and on access to health and nutrition services }\end{array}$ & 311.54 & 272.18 & -3.481 & .000 \\
\hline $\begin{array}{l}\text { 5. Identify general danger signs among sick children, recognise symptoms of common illnesses and Enable } \\
\text { prompt referral. }\end{array}$ & 317.42 & 267.05 & 4.525 & 000 \\
\hline
\end{tabular}

The level of satisfaction with regard to objectives was higher in ASHAs of Indore than in ASHAs of Dewas. Difference was statistically significant (Mann - Whitney U test, $\mathrm{p}<0.05$ ).

\section{Satisfaction with regard to course material:} The reaction regarding course material relevance, appropriateness, and its practical applicability was good. 94\% trainees agreed the knowledge and skills they learnt here will be very useful for their work. Only $1 \%$ disagreed with the course relevance and $5 \%$ shown neutral reactions. Overall quality of course was very high according to $75 \%$ of the trainees.

\section{Reaction of trainees regarding training process} and training centre facilities: $86 \%$ participants satisfied with their queries solved and 90\% agree that the teachers were efficient in teaching. Only $65 \%$ trainees were satisfied with overall facilities while $15 \%$ felt the facilities unsatisfactory for effective learning and $20 \%$ shown neutral response regarding this. The overall facilities were more comfortable in Indore on physical observation and as per participant's feedback.

Table-4: Comparison of Indore and Dewas for Satisfaction with course material training process and training centre facilities:

\begin{tabular}{|l|l|l|l|l|}
\hline \multicolumn{1}{|c|}{ Mann-Whitney U test } & $\begin{array}{r}\text { Mean rank } \\
\text { Indore }\end{array}$ & $\begin{array}{r}\text { Mean rank } \\
\text { Dewas }\end{array}$ & $\begin{array}{c}\mathbf{Z} \\
\text { score }\end{array}$ & $\begin{array}{c}\mathbf{P} \\
\text { value }\end{array}$ \\
\hline Course relevant to work & 289.04 & 291.77 & -.388 & .698 \\
\hline $\begin{array}{l}\text { Committed to apply what } \\
\text { learned to my job. }\end{array}$ & 289.04 & 291.77 & -.388 & .698 \\
\hline $\begin{array}{l}\text { The level of the course met my } \\
\text { needs. }\end{array}$ & 289.04 & 291.77 & -.388 & .698 \\
\hline $\begin{array}{l}\text { The supplemental materials } \\
\text { were appropriate. }\end{array}$ & 289.04 & 291.77 & -.388 & .698 \\
\hline $\begin{array}{l}\text { My questions were adequately } \\
\text { resolved. }\end{array}$ & 324.71 & 260.70 & -7.504 & .000 \\
\hline
\end{tabular}

\begin{tabular}{|l|l|l|l|l|}
\hline The teaching effectiveness of was excellent. & 310.20 & 273.34 & -4.593 & .000 \\
\hline $\begin{array}{l}\text { Technical support was adequate and helpful } \\
\text { while completing the course. }\end{array}$ & 302.91 & 279.69 & -1.864 & .000 \\
\hline The facility was conducive to learning. & 430.51 & 168.56 & -19.56 & .000 \\
\hline
\end{tabular}

Participants from both the district were satisfied with the course material. No significant difference in satisfaction level was found among participants of Indore and Dewas,

Participants from Dewas were less satisfied with explanation of their questions and queries compared to Indore and the difference was statistically significant. Similarly the teaching effectiveness was found to be superior in Indore as compared to Dewas as there was significant difference in satisfaction level of participants from both the districts. Use of technology in the training / teaching had helped a lot in learning as $93 \%$ trainees were in favour of this.

\section{Discussion}

ASHAs are the front line health personnel available in the rural areas to solve health emergencies and health needs of the people. Government through NRHM is making lots of effort to strengthen the ASHA programme by selection and training process.

There was lack of basic facilities like separate dormitories, mess, dining hall, adequate number of toilets in the Dewas training centre. Though centre in Indore district, had most of the basic facilities, lacks extended facilities of crèche and facility for recreation (Table 1 ).

Training centres at both the districts followed the training plan and schedule but there was delay in the start-up of session on the first day of training. It was also found that most of ASHAs come late at the training centre on first day instead of a day before in the evening as per guidelines (Table 2). 
The average age of ASHAs in our study was around 28 years slightly lower compared to study done by Bajpayi N. et al (2010)10 which was in Bihar (31years), Utter Pradesh (31years), Rajasthan (33 years) and Chhattisgarh (32). Also in our study one fourth of ASHAs had less than essential qualification (class 8th) which was similar to the study by Bajpayi $\mathrm{N}$. et al[10] in 2010 where $28 \%$ of the ASHAs from Chhattisgarh were below class 8th standard.

The reaction or feedback of trainees (ASHAs) revealed that more than $70 \%$ of the participants were satisfied with objectives i.e. know how to perform different activities for new born care, care of sick child, counsel mothers for baby feeding, prevent new born from hypothermia and educate mothers for prevention of child malnutrition (Table 3 ). The rate of satisfaction (number/ proportion of ASHA who agree) was significantly high in trainees of Indore compared to that of Dewas for each objective (Mann Whitney $U$ test, $P<0.000$ ). Satisfaction with regard to course relevancy was similar in both the districts $(P=0.698) .94 \%$ of trainees agreed with course material adequacy and utility. $86 \%$ trainees agreed with trainer's good ability to clarify queries and questions, and $74 \%$ agreed with their good teaching efficiency. There was significant difference between trainees of Indore and Dewas with regard to teaching effectiveness and ability of trainers to clarify doubts, satisfaction rate higher in Indore (Table 4).

The satisfaction results with course material and trainers were similar to the study by Janet Brandling et al "Evaluating Mental Health First Aid Training for Line Managers working in the public sector [11]" 2010 where the course evaluation results indicated a strong personal identification and satisfaction with the training. This was particularly evident in relation to the trainer and also the course materials such as the manual, where the results were overwhelmingly positive. Only $65 \%$ of the trainees were satisfied with the overall facilities at the training centres. $70 \%$ of trainees complained that the training hours were too long and they get tired of it especially in the evening sessions. $50 \%$ of the ASHAs from Dewas complained of inadequate facility for residential training, space and bathroom /toilet facility.

Similarly Janet Brandling et al [11] 2010 in his study found signs of dissatisfaction related to the venues, namely the clinical skills lab in Chippenham and the Alzheimers centre in Devizes.
They found Chippenham venue not being suitable for this type of training, with computer terminals and hospital furniture; and the Devizes venue being too cramped creating a slightly claustrophobic feeling.

The reaction was similar as in study by Bhatt $\mathrm{H}$. et al [12] in Uttrakhand in year 2012, where most of the ASHAs admit that the training is beneficial, nearly half of them don't consider the training to be adequate. Also in study by Bajpayi N. et al[10] in 2010 most of the trainees were satisfied with training activity and those who were not satisfied wanted a repeat training. The percentage of ASHAs needing to repeat training overall was lowest in Bihar, highest in Chhattisgarh.

\section{Conclusions}

Thus the overall facilities for training were better in Indore compared to Dewas. The satisfaction among ASHAs regarding teaching techniques and aids, teachers skills was higher in Indore (statistically significant, Mann Whitney $U$ test, $P<0.05$ ). Majority of ASHAs of Indore also agreed that the facilities at training centre were conductive for training while ASHAs at Dewas had complain of lack of facilities for residential training at their training centre. The feedback of trainees regarding fulfilment of objectives and course material was good at both the training centre and had no difference.

The study revealed that there were many deficiencies in the facilities for proper conduction of training. To overcome this, selection of NGOs for training should be done only after verification and confirmation of the availability of required facilities for organising training. There was also deficiency in proper implementation of training plan resulting in delay in starting the session. Training In-charge should ensure the presence of trainers and trainees in time and timely inauguration of the training.

To stop the nuisance and disturbance caused by children accompanied to participant ASHAs a separate baby room/ crèche facility to babies of mother trainees/ ASHAs and recreation and entertainment facility to make trainees stay more comfortable. Further to improve the quality of training an additional training In-charge can be appointed from district health administration apart from the In-charge from NGOs and Strict supervision and monitoring should be done by appropriate authority. 


\section{Reference}

01. Ministry of Health and Family Welfare (MoHFW). ASHA. Government of India. 2005. [Article] [Crossref]

02. Government of India. National Rural Health Mission (2005-2012) Mission Document. New Delhi- Ministry of Health and Family Welfare. 2005.

Available at: [Article/a>] [Crossref]

03. National Institute of Health \& Family Welfare report. "A study to Assess Factors at Peripheral Level for Effective Implementation of ASHA Scheme" in Utter Pradesh.

Available at [Article] [Crossref]

04. Update on ASHA programme. July 2011, Jan 2012 and July 2012.

Available at: [Article] [Crossref]

05. Guidelines for Community Processes. NRHM, Ministry of Health and Family Welfare. Government of India. 2013.

Assessed through [Article] [Crossref]

06. 7th update on ASHA programme. Jan 2013.

Available at: [Article] [Crossref]

07. Shashank K J, Angadi MM, Masali KA, Wajantri P, Bhat S, Jose AP. "A study to evaluate working Profile of accredited social Health activist (ASHA) and to Assess their knowledge about Infant health care". IJCRR. 2013;5(12)97-103. [Crossref]

08. Creative research system survey software. Available at: [Article] [Crossref]

09. User guide and resource manual, workforce development plan. center for public health practice, the Ohio state university. 2012. Assessed through [Article] [Crossref]

10. Bajpai N, Dholakia RH. "Improving the performance of accredited social health activists in India". Working Paper No 1 May 2011.

[Crossref]
11. Brandling J, et al. "Evaluating Mental Health First Aid Training for Line Managers working in the public sector". 2010.

[Crossref]

12. Bhatt $H$. A rapid appraisal of functioning of ASHA under NRHM in Uttarakhand, India. May 2012.

Assessed through: [Article] [Crossref] 